\title{
Improving Student's Interest and Learning Outcome in Science about Single and Mixed Substances Applying Discovery Learning Assisted by ICT Media on Fifth Grade Students of SDN 2 Darmakradenan
}

\author{
Juriyah \\ SDN 2 Darmakradenan \\ juriyahpgsd@gmail.com
}

\section{Article History}

received 3/12/2020

revised $17 / 12 / 2020$

accepted 31/12/2020

\begin{abstract}
This research aimed to find out the effect of applying Discovery Learning assisted by ICT media towards student's interest and learning outcome in science about single and mixed substances of a total of 12 students on fifth grade of SDN 2 Darmakradenan. This classroom action research was conducted with a cyclical process consisted of 4 stages; plan, action, observation, and reflection, in 2 cycles. Based on the observation result of student's interest, only 33,33\% of precycle showed their interest. Then, after first cycle, it improved 66,67\%, and later improved to $91,67 \%$ at the end of second cycle. Based on the formative test result, only 41,67 of the pre-cycle passed the course. Then, it improved $75,00 \%$ in first cycle, and at the end of second cycle $100,00 \%$ passed the course. On the pre-cycle, the class's average grade is about 55.56, and it improved to 83,33 after second cycle. Based on the analysis above, it can be concluded that Discovery Learning Assisted ICT Media can improve student's interest and learning outcome on fifth grade students of SDN 2 Darmakradenan in science about single and mixed substances.
\end{abstract}

Keywords: learning outcome, learning interest, discovery learning, ICT media

\section{Abstract}

Penelitian ini bertujuan untuk mengetahui efektivitas penerapan model pembelajaran Discovery Learning berbantuan media ICT terhadap minat dan hasil belajar IPA materi zat tunggal dan zat campuran pada peserta didik kelas V SDN 2 Darmakradenan yang berjumlah 12 peserta didik. Penelitian ini meliputi empat tahap yaitu perencanaan (plan), pelaksanaan (action), observasi (observation), dan refleksi (reflection) dalam dua siklus. Berdasarkan hasil observasi terhadap minat belajar peserta didik pada kondisi pra siklus hanya $33,33 \%$ dari total peserta didik yang menunjukkan minat belajar, kemudian setelah dilaksanakan perbaikan pada siklus I peserta didik yang menunjukkan minat belajar meningkat menjadi $66,67 \%$ dan pada akhir perbaikan pembelajaran pada siklus II meningkat menjadi $91,67 \%$. Berdasarkan hasil tes formatif dari pra siklus hanya $41,67 \%$ yang tuntas KKM, kemudian meningkat pada siklus I menjadi $75,00 \%$. Pada akhir siklus II dihasilkan ketuntasan belajar $100 \%$. Pada kondisi pra siklus nilai rata-rata kelas sebesar 55,56 , setelah dilaksanakan perbaikan Siklus II naik menjadi 83,33. Berdasarkan hasil analisis, dapat disimpulkan bahwa melalui penggunaan model pembelajaran Discovery Learning Berbantuan Media ICT mampu meningkatkan minat dan hasil belajar IPA materi zat tunggal dan zat campuran.

Kata Kunci: hasil belajar, minat belajar, discovery learning, media ICT

Social, Humanities, and Education Studies (SHEs): Conference Series https://jurnal.uns.ac.id/shes 


\section{PENDAHULUAN}

Kompetensi guru yang meliputi kompetensi kepribadian, kompetensi profesional, kompetensi sosial, dan kompetensi pedagogik perlu dikontekstualisasikan dan dilakukan penyesuaian sehingga mampu mempersiapkan dan memprediksi kebutuhan belajar peserta didik abad 21 dan tuntutan masyarakat abad 21. Ilmu Pengetahuan Alam (IPA) berhubungan dengan cara mencari tahu tentang alam secara sistematis, sehingga IPA bukan hanya penguasaan kumpulan pengetahuan yang berupa fakta-fakta, konsepkonsep, atau prinsip-prinsip saja tetapi juga merupakan suatu proses penemuan. Pendidikan IPA diharapkan dapat menjadi wahana bagi peserta didik untuk mempelajari diri sendiri dan alam sekitar, serta prospek pengembangan lebih lanjut dalam menerapkannya di dalam kehidupan sehari-hari. Proses pembelajarannya menekankan pada pemberian pengalaman langsung untuk mengembangkan kompetensi agar menjelajahi dan memahami alam sekitar secara ilmiah.

Guru sebagai bagian dari penggerak dibidang pendidikan memiliki peran yang sangat penting dalam upaya peningkatkan pengetahuan dan keterampilan peserta didik. Untuk itu, guru harus mampu mendorong kreatifitas dan kemampuan peserta didik dalam berfikir dan berinovasi, sehingga dapat diperoleh prestasi dan keterampilan yang optimal. Guru dituntut bisa mengembangkan perangkat pembelajaran secara daring dan memanfaatkan TIK. Namun kondisi ideal tersebut masih jauh berbeda dari kenyataan yang terjadi di lapangan. Melihat situasi dan kondisi dimasa pandemi COVID-19 seperti ini, pembelajaran diharuskan dilaksanakan secara daring sesuai kebijakan Pemerintah Daerah Kabupaten Banyumas yang termasuk dalam zona oranye. Pembelajaran daring adalah Pembelajaran yang dilakukan secara virtual atau menggunakan aplikasi virtual yang terkoneksikan dengan internet. Fasilitas yang memadai menunjang terjadinya pembelajaran jarak jauh sistem daring serta perkembangan teknologi dan komunikasi yang ada di indonesia mempengaruhi jumlah penggunaan internet.

Sudirman (2013:38) mendefinisikan minat sebagai suatu keadaan di mana seseorang memiliki perhatian yang besar terhadap suatu objek yang disertai dengan keinginan untuk mengetahui dan mempelajari hingga akhirnya membuktikan lebih lanjut tentang objek tersebut. Menurut Slameto (2010:180) mengatakan minat tidak dibawa sejak lahir, melainkan diperoleh kemudian. Guru perlu membangkitkan minat siswa agar pelajaran yang diberikan mudah dipahami siswa. Minat dapat mempengaruhi pencapaian hasil belajar siswa. siswa yang menaruh minat besar terhadap pelajaran maka siswa tersebut memiliki perhatian yang lebih dibandingkan dengan siswa lainnya. Dari perhatian yang lebih itulah, siswa tersebut akan lebih rajin untuk belajar yang akhirnya akan berpengaruh terhadap hasil belajar siswa. Menurut. Muhibbinsyah (2010: 133) terdapat dua faktor yang mempengaruhi minat belajar siswa, yaitu faktor dari dalam (sifat pembawaan seseorang) dan faktor dari luar (keluarga, sekolah, dan masyarakat atau lingkungan).

Kegiatan belajar-mengajar hendaknya tidak hanya berfokus pada guru, tetapi juga harus melibatkan siswa. Artinya pembelajaran harus melibatkan kemampuan siswa secara maksimal untuk menggali dan mengidentifikasi sehingga mereka dapat menemukan pengetahuan dengan sendiri. Pembelajaran ini disebut pembelajaran penemuan (Discovery Learning). Hal sependapat juga dikemukakan oleh Bruner dalam Arends (2008) Discovery Learning merupakan sebuah metode pengajaran yang menekankan pentingnya membantu siswa untuk memahami struktur atau ide-ide kunci suatu disiplin ilmu, kebutuhan akan keterlibatan aktif siswa dalam proses belajar, dan keyakinan bahwa pembelajaran sejati terjadi melalui personal discovery. Berbagai pendapat telah dijelaskan oleh beberapa ahli mengenai pembelajaran penemuan, sejalan dengan hal tersebut Agus N. Cahyo, (2013:100) mengatakan "Discovery Learning adalah metode mengajar yang mengatur pengejaran sedemikian rupa 
sehingga anak memperoleh pengetahuan yang sebelumnya belum diketahuinya tidak melalui pemberitahuan, tetapi menemukan sendiri.

Media adalah adalah manusia, materi, atau kejadian yang membangun kondisi, yang membuat siswa mampu memperoleh pengetahuan, ketrampilan, atau sikap [13]. Menurut Zainiyati (2017: 117) Media pembelajaran berbasis ICT (Information, Communication, Technology) adalah alat yang digunakan dalampembelajaran dengan memanfaatkan teknologi informasi dan komunikasi (TIK). Sedangkan menurut Nursamsu (2017) dalam jurnal penelitiannya menyebutkan bahwa ICT (Information, Communication, Technology) atau TIK merupakan suatu media pembelajaran yang mencangkup aspek kemajuan dalam penggunaan teknologi informasi, yang dalam pelaksanaannya dapat meningkatkan mutu pendidikan. Peneliti juga membandingkan dengan hasil penelitian yang dilakukan oleh Nicken Fitriana (2019) dengan judul Peningkatan hasil belajar ipa tentang materi melalui metode discovery bebantu media ICT (information, communication, technology) pada siswa kelas $v$ mim girimargo kecamatan miri kabupaten sragen tahun pelajaran 2018/2019, menunjukan adanya respon positif dari peserta didik.

Berdasarkan hasil observasi peneliti dalam melaksanakan pembelajaran tematik pada muatan pelajaran IImu Pengetahuan Alam (IPA) kelas V SDN 2 Darmakradenan KD 3.9 Mengelompokan materi dalam kehidupan sehari-hari berdasarkan komponen penyusunnya (Zat tunggal dan campuran) yang dilaksanakan secara daring diperoleh informasi bahwa terdapat kendala dalam pelaksanaan pembelajaran yang telah dilaksanakan. Salah satu kendala tersebut adalah guru hanya menggunakan metode pembelajaran yang dikuasainya saja yaitu ceramah dan penugasan (konvensional), sehingga siswa menjadi bosan dan tidak bersemangat dalam mengikuti pembelajaran. Setelah dilakukan tes formatif tenyata hasilnya dari 12 siswa hanya 5 siswa $(41,67 \%)$ yang memenuhi KKM yakni 70 , sedangkan 8 siswa $(58,33 \%)$ memperoleh nilai di bawah KKM.

Penelitian ini bertujuan untuk mengetahui dampak penggunaan model pembelajaran Discovery Learning berbantuan media ICT (Information, Communication and Technology) terhadap minat dan hasil belajar IPA materi zat tunggal dan campuran bagi siswa kelas V SDN 2 Darmakradenan Tahun Pelajaran 2019/2020. Selain itu, memberikan penjelasan berdasarkan bukti empiris bahwa penggunaan model pembelajaran Discovery Learning berbantuan media ICT (Information, Communication and Technology) mampu meningkatkan minat dan hasil belajar pada peserta didik kelas V SDN 2 Darmakradenan.

\section{METODE}

Jenis penelitian yang dilakukan merupakan Penelitian Tindakan Kelas (PTK) atau Classroom Action Research (CAR). Penelitian Tindakan Kelas (PTK) yaitu suatu bentuk penelitiam yang dilaksanakan untuk memecahkan masalah yang dihadapi dalam pelaksanaan proses pembelajaran (Suranto, 2010: 10). Tindakan tersebut dilakukan oleh guru atau dengan arahan dari guru yang dilakukan oleh peserta didik (Arikunto, 2012:3). Penelitian dilaksanakan di kelas V SDN 2 Darmakradenan pada semester II Tahun Pelajaran 2019/2020, yaitu pada bulan April - Mei 2020. Subjek dalam penelitian ini adalah seluruh peserta didik kelas V Yang berjumlah 12 peserta didik, 6 laki-laki dan 6 perempuan. Model pembelajaran Discovery Learning berbantuan media ICT merupakan variabel bebas $(X)$. Sedangkan variabel terikat $(Y)$ yaitu minat dan hasil belajar merupakan output yang dimiliki peserta didik sebagai hasil pemrosesan input selama kegaitan pembelajaran.

Adapun prosedur penelitian yang dipilih yaitu dengan menggunakan model Stephen Kemmis dan Roin Mc Taggart. Model ini meliputi tahapan perencanaan (planning), tindakan (action) dan observasi (observation), dan refleksi (reflection) 
yang saling terkait satu sama lain. Kemudian diikuti dengan perencanaan ulang yang dilaksanakan dalam bentuk siklus tersendiri (Zainal, 2011:22). Teknik pengumpulan data dilakukan dengan cara observasi (dilakukan selama proses pembelajaran), tes (dilaksanakan pada akhir pembelajaran setiap siklus), dan dokumentasi (melihat situasi pada saat proses pembelajaran) (Sugiyono, 2013: 329).

\section{HASIL DAN PEMBAHASAN}

Pada kondisi pra siklus peneliti melakukan pengamatan terhadap minat dan hasil belajar peserta didik pada pembelajaran IPA materi zat tunggal dan zat campuran. Dari hasil tes yang telah dilakukan pada pra siklus diperoleh data nilai rata-rata kelas sebesar 55,96, peserta didik yang memenuhi KKM sebanyak 4 peserta didik dari 12 peserta didik atau sebesar 33,33\%. Sementara Kriteria Ketuntasan Minimal mata pelajaran IPA di SDN 2 Darmakradenan adalah 70. Data tersebut membuktikan hasil yang diperoleh masih rendah dan jauh dari harapan.Sementara data hasil observasi minat belajar peserta didik menunjukan ada 5 dari 12 peserta didik yang menunjukan minat belajar atau baru 41.67\%. Data tersebut menujukan bahwa minat belajar terhadap mata pelajaran IPA materi zat tunggal dan zat campuran masih rendah dan jauh dari harapan.

Implementasi siklus I dilakukan dengan tahapan: perencanaan, tindakan, observasi, dan refleksi. RPP disusun dengan alokasi waktu selama 3 × 35 menit. Langkah-langkah pembelajaran dalam RPP dikembangkan dengan mengikuti sintaks model pembelajaran Discovery Learning berbantuan media ICT. Berdasarkan observasi pada siklus I menunjukkan minat belajar peserta didik dalam pembelajaran IPA dengan model Discovery Learning berbantuan media ICT mengalami peningkatan. Jika dibandingkan pada hasil observasi minat belajar pada pra siklus, diketahui semua aspek minat belajar mengalami peningkatan pada siklus I.

Berikut ini minat belajar IPA peserta didik kelas V SDN 2 Darmakradenan disajikan dalam Tabel 1.

Tabel 1 Rekapitulasi Minat Belajar IPA Pada Siklus I

\begin{tabular}{clcc}
\hline No & Pembelajaran & $\begin{array}{c}\text { Peserta didik menunjukkan } \\
\text { minat }\end{array}$ & Persentase \\
\hline 1 & Pra Siklus & 4 & $33,33 \%$ \\
2 & Siklus I & 8 & $66,67 \%$ \\
\hline
\end{tabular}

Berdasarkan data di tabel 1, diketahui sebelum tindakan hanya 4 peserta didik yang menunjukkan minat dalam mengikuti pelajaran atau 33,33\% dari 12 peserta didik. Pada siklus I, peserta didik yang telah menunjukkan minat dalam mengikuti pelajaran naik menjadi 8 peserta didik atau $66,67 \%$ dari 12 peserta didik. Dari sebelum perbaikan ke siklus I, mengalami kenaikan sebanyak $33,33 \%$. Selain observasi minat belajar peserta didik, pengukuran juga dilakukan terhadap hasil belajar IPA guna mengetahui ketercapaian pembelajaran IPA dengan menerapkan model Discovery Learning berbantuan media ICT. Berikut ini hasil belajar IPA peserta didik kelas V SDN 2 Darmakradenan disajikan dalam Tabel 2. 
Tabel 2 Rekapitulasi Ketuntasan Hasil Belajar IPA Pada Siklus I

\begin{tabular}{llccccc}
\hline No & Pembelajaran & $\begin{array}{c}\text { Nilai } \\
\text { Rata-rata } \\
\text { Kelas }\end{array}$ & Tuntas & Persentase & Belum & Persentase \\
\hline 1 & Pra Siklus & 55,50 & 5 & $41,67 \%$ & 7 & $58,33 \%$ \\
2 & Siklus I & 71,67 & 9 & $75,00 \%$ & 3 & $25,00 \%$
\end{tabular}

Berdasarkan data pada tabel 2 , diketahui pada pra siklus nilai rata-rata kelas 55,00 , setelah dilakukan perbaikan mengalamai kenaikan menjadi 71,67. Rata-rata kelas naik 16,67 . Pada pra siklus dari 12 peserta didik hanya 5 peserta didik yang tuntas KKM ( $\geq 70)$ atau $41,67 \%$, setelah diakukan perbaikan pada siklus I terdapat kenaikan jumlah peserta didik yang tuntas menjadi 9 peserta didik atau $75,00 \%$.

Meski demikian, hasil tersebut belum mencapai indikator penelitian yaitu $80 \%$ peserta didik telah tuntas di atas KKM $(\geq 70)$. Temuan-temuan pada siklus I menunjukkan bahwa perlu upaya perbaikan proses pembelajaran agar indikator penelitian tersebut dapat tercapai. Beberapa masalah yang terjadi selama pembelajaran berlangsung pada siklus I antara lain pada awal pertemuan banyak peserta didik yang masih bingung dalam mengikuti langkah - langkah pembelajaran Discovery Learning. Terdapat empat peserta didik yang tidak aktif dalam pembelajaran salah satunya disebabkan karena tidak memungkinkan untuk mengikuti kegiatan pembelajaran secara daring dan kegiatan percobaan secara kelompok. Kerjasama antar peserta didik juga sudah belum maksimal dalam melakukan percobaan/pengamatan dan saat mempresentasikan hasil kerja. Penelitian dilanjutkan ke siklus II dengan memperbaiki dan lebih mengoptimalkan pembelajaran sesuai dengan hasil refleksi. Perbaikan tersebut diantaranya guru lebih memberikan bimbingan kepada peserta didik selama langkah-langkah pembelajaran secara daring model Discovery Learning berbantuan media ICT, peserta didik diarahkan untuk melakukan percobaan secara individu karena menyesuaikan dengan kondisi pandemi Covid-19.

Pelaksanaan siklus II diimplementasikan sebanyak 2 pertemuan, masing-masing pertemuan alokasi waktu pembelajaran yakni $3 \times 35$ menit. Pembelajaran dilakukan dengan memperhatikan masukan- masukan pada hasil refleksi siklus I. Data observasi pada minat belajar siklus II terdapat pada Tabel 3.

Tabel 3 Rekapitulasi Minat Belajar IPA Pada Siklus II

\begin{tabular}{|c|c|c|c|c|}
\hline No & Pembelajaran & $\begin{array}{l}\text { Peserta didik } \\
\text { minat }\end{array}$ & menunjukkan & Persentase \\
\hline 1 & Pra Siklus & & 4 & $33,33 \%$ \\
\hline 2 & Siklus I & & 8 & $66,67 \%$ \\
\hline 3 & Siklus II & & 11 & $91,67 \%$ \\
\hline
\end{tabular}

Temuan data pada tabel 3 diketahui minat belajar pembelajaran IPA siklus II meningkat. Pada Pra Siklus hanya 4 peserta didik dari 12 peserta didik yang telah menunjukkan minat dalam mengikuti pelajaran atau 33,33\%. Pada siklus I, peserta didik yang telah menunjukkan minat belajar naik menjadi 8 dari 12 peserta didik atau $66,67 \%$. Pada siklus II, peserta didik yang telah menunjukan minat belajar naik menjadi 11 peserta didik atau 91,67\% . Selain itu, pengukuran hasil belajar IPA 
dilakukan guna mengetahui ketercapaian hasil belajar peserta didik kelas V SDN 2 Darmakradenan disajikan dalam bentuk tabel 4 .

Tabel 4. Rekapitulasi Ketuntasan Hasil Belajar IPA Pada Siklus II

\begin{tabular}{lcccccc}
\hline No & Pembelajaran & $\begin{array}{c}\text { Nilai } \\
\text { Rata- } \\
\text { rata } \\
\text { Kelas }\end{array}$ & Tuntas & Persentase & Belum Persentase \\
\hline 1 & Pra Siklus & 55,50 & 5 & $41,67 \%$ & 7 & $58,33 \%$ \\
2 & Siklus I & 71,67 & 9 & $75,00 \%$ & 3 & $25,00 \%$ \\
3 & Siklus II & 85,83 & 12 & $100 \%$ & 0 & $0 \%$ \\
\hline
\end{tabular}

Temuan tabel 4 diketahui hasil belajarpeserta didik pada siklus II mengalami peningkatan. Pada Pra siklus nilai rata-rata kelas 55,00 setelah dilakukan tindakan perbaikan pembelajaran pada siklus I nilai rata-rata naik menjadi 71,67. Pada siklus II nilai rata-rata naik menjadi 85,83 . Jumlah peserta didik yang telah mencapai KKM $(\geq 70)$ adalah 12 peserta didik $(100 \%)$ atau bertambah 3 peserta didik $(25,00 \%)$ dari siklus I dan bertambah 4 peserta didik (33,33\%) dari pra siklus. Temuan tabel 4 diketahui hasil belajarpeserta didik pada siklus II mengalami peningkatan. Data hasil observasi tentang minat dan hasil belajar menjadi bahan kajian refleksi oleh peneliti. Ketuntasan klasikal pada siklus II menunjukkan $100 \%$. Data ini menunjukkan hasil tersebut telah melampaui indikator penelitian yaitu $80 \%$ peserta didik telah tuntas di atas KKM ( $\geq 70)$. Oleh karena itu, pelaksanaan penelitian tindakan kelas ini dapat dihentikan pada siklus II.

Penerapan model Discovery Learning berbantuan media ICT dipandang mampu meningkatkan minat dan hasil belajar peserta didik di kelas V SDN 2 Darmakradenan. Pada indikator semangat dan antusias mengikuti kegiatan pembelajaran daring telah meningkat menjadi sangat baik. Adapun pemusatan perhatian peserta didik dalam menemukan informasi melalui media ICT juga menjadi kategori sangatbaik. Selain dua aspek tersebut, dua aspek minat belajar lainnya juga mengalami peningkatan sepertiaspek ketertarikan dan keingintahuan terhadap materi menjadi kategori sangat baik. Adapun data hasil belajar pada pembelajaran IPA juga meningkat dengan perolehan ketuntasan klasikal menjadi $100 \%$.

\section{SIMPULAN}

Simpulan penelitian ini adalah penerapan model pembelajaran Discovery Learning berbantuan media ICT dapat meningkatkan minat belajar peserta didik kelas V SDN 2 Darmakradenan tahun ajaran 2019/2020 dalam pembelajaran IPA materi zat tunggal dan campuran. Peningkatan kualitas proses pembelajaran dapat dibuktikan dari peningkatan minat belajar peserta didik pada keempat indikatornya dari pra siklus meningkat pada siklus I, dan kembali meningkat pada siklus II. Keempat indikator minat belajar pada penelitian ini meliputi pemusatan perhatian peserta didik terhadap pelajaran, ketertarikan peserta didik terhadap materi pelajaran, keingintahuan peserta didik dengan mengajukan pertanyaan, dan sikap semangat/antusias peserta didik dalam melakukan percobaan/pengamatan. Selain itu, penerapan model Discovery Learning berbantuan media ICT dapat meningkatkan hasil belajar peserta didik ditandai dengan peningkatan ketuntasan klasikal pada pra siklus sebesar $41,67 \%$ meningkat pada siklus 1 menjadi $75,00 \%$, dan kembali meningkat pada siklus II menjadi $100 \%$. 
Penelitian ini memberikan implikasi teoritis bahwa model pembelajaran Discovery Learning berbantuan media dapat menjadi referensi sebagai model inovatif untuk meningkatkan minat dan hasil belajar peserta didik di sekolah dasar. Minat belajar peserta didik dalam pembelajaran merupakan wujud nyata desain pembelajaran yang berpusat pada siswa sehingga siswa tidak hanya sebagai objek belajar. Adapun implikasi praktis penelitian ini adalah berkenaan dengan sekolah, guru, dan peserta didik. Sekolah dapat menambah koleksi perpustakaan serta menyediakan referensi bagi guru tentang penelitian tindakan kelas. Guru/peneliti memeroleh pengalaman dalam menerapkan dan mengembangkan pembelajaran dengan model pembelajaran Discovery Learning berbantuan media ICT dalam mata pelajaran IPA. Peserta didik dapat belajar secara aktif, kreatif dan menyenangkan dengan pelaksanaan pembelajaran Discovery Learning berbantuan media ICT, serta meningkatkan kemampuan peserta didik dalam pelajaran IPA.

\section{DAFTAR PUSTAKA}

Arends, R.I. (2007). Learning to Teach, Belajar Untuk Mengajar buku 2, Terjemahan oleh Helly Prajitno Soetjipto, dan Sri Mulyantini Soetjipto, 2008, Yogyakarta, Pustaka Pelajar.

Arikunto, S. (2012). Penelitian Tindakan Kelas. Jakarta: Bumi Aksara

Cahyo, Agus N. (2013). Panduan Aplikasi Teori-Teori Belajar Mengajar Teraktual dan Terpopuler. Yogyakarta : Diva Press.

I. Pembelajaran, D. Untuk, M. Mutu, P. Sebagai, D. Diterapkannya, and S. Distancing, "Albitar Septian Syarifudin Universitas Trunojoyo Madura , Jalan Raya Telang , Bangkalan," pp. 31- 34, 2020.

Muhibbinsyah. (2010). Psikologi Pendidikan.Bandung: Remaja Rosdakarya.

Niken Fitriana. (2019). Peningkatan hasil belajar ipa tentang materi melalui metode discovery bebantu media ICT (information, communication, technology) pada siswa kelas $v$ mim girimargo kecamatan miri kabupaten sragen tahun pelajaran 2018/2019.

Nursamsu, \& Kusnafizal, T. (2017). Pemanfaatan Media Pembelajaran ICT Sebagai Kegiatan Pembelajaran Siswa Di SMP Negeri Aceh Tamiang. Jurnal IPA dan Pembelajaran IPA (JIPI), 1(2), 165-170.

Peraturan Menteri Pendidikan Nasional No 22 Tahun 2006 tentang Standar Kompetensi dan Kompetensi Dasar Tingkat SD, MI, dan SDLB, hlm. 417

Pujiriyanto. (2019). Peran Guru Dalam Pembelajaran Abad 21.Jakarta.

Salahudin, Anas. (2015). Penelitian Tindakan Kelas. Bandung: CV Pustaka Setia.

Sanjaya, W. (2006). Strategi Pembelajaran. Jakarta: Kencana Prenada Media Group.

Sardiman, A.M. (2008). Interaksi dan Motivasi Belajar Mengajar. Jakarta: PT. Raja Grafindo Persada.

Siti Fatonah dan Zuhdan K. Prasetyo. (2014). Pembelajaran Sains. Yogyakarta: Ombak.

Slameto. (2010). Belajar dan Faktor-faktor yang Mempengaruhinya. Jakarta: Rineka Cipta.

Sudirman. (2013). Pembentukan Minat. Jakarta : Pustaka Karya.

Suranto, Sukidin, dan Basrowi. (2010). Manajemen Penelitian Tindakan Kelas. Jakarta: Insan Cendekia

Zainiyati, H.S. (2017). Pengembangan media pembelajaran berbasis ICT Konsep dan Aplikasi pada pembelajaran pendidikan Agama Islam. Jakarta : Kencana 